\title{
Influence of planting norms and harvest term on Sudan grass (Sorghum $\times$ drummondii) yield
}

\author{
Khalima Atabayeva $^{1 *}$, Guljakhon Mirsharipova ${ }^{2}$, Davron Mustafakulov ${ }^{1}$, Alisher \\ Musurmonov $^{2}$, Laziza Botirova ${ }^{2}$, and Mahliyo Kurbonova ${ }^{2}$ \\ ${ }^{1}$ Tashkent State Agrarian University, 100140 Tashkent province, Uzbekistan \\ ${ }^{2}$ Gulistan State University, Gulistan, Sirdarya province, Uzbekistan
}

\begin{abstract}
Sudan grass (Sorghum $\times$ drummondii) is grown after alfalfa and corn as the main fodder crops in developed countries. Sudan grass is a perennial plant that is resistant to salt and drought. This article provides information on the effects of planting Sudan grass at different rates and harvesting at different times in saline soils of the Syrdarya province, Uzbekistan, on plant growth, yield formation and nutrient quality. Sufficient results were obtained when Sudan grass was planted at $25 \mathrm{~kg}$ per hectare and harvested at 50\% flowering phase. Experiments were carried out in soil-climatic conditions of the experimental production base of the Syrdarya Scientific Experimental Station of the Research Institute of Cotton Breeding, Seed Production and Cultivation Agrotechnologies.
\end{abstract}

\section{Introduction}

It is important to provide the world's population with food, including livestock products. Therefore, one of the important tasks is to increase the production of livestock products from year to year and improve its quality [1]. To fulfill this task, it is necessary, first of all, to create a stable fodder base in the livestock sector. It is known that the main part of the total feed balance of livestock consists of feed prepared from plants, that is, they account for $95 \%$ of the feed unit [2]. Therefore, the development of fodder production in fields and pastures is crucial in strengthening the fodder base of livestock. Sudan grass (Sorghum $\times$ drummondii) is grown after alfalfa and corn as the main fodder crops in developed countries [3].

In the world today, Sudan grass is grown as a staple fodder crop in the south-northern provinces of America, northeastern Africa, Australia, Southern Europe, India, southeastern Russia, the Altai Krai, the Far East, Ukraine and Kazakhstan. The average green yield is 40 tons/ha $[3,4]$.

In recent years, Uzbekistan has also paid special attention to the development of the livestock sector, strengthening its fodder base, efficient use of saline soils, increasing the productivity and selection of crops that can improve the quality of animal feed and the technology of their cultivation [5].

\footnotetext{
* Corresponding author: atabaeva1935@mail.ru
} 
Based on the above considerations, it is expedient to determine and introduce into production the effect of sowing norms and harvesting time on the yield of Sudan grass, its nutrients in the saline soil conditions of the Syrdarya province [6].

The biological properties of Sudan grass are heat-loving, drought-resistant, salt-tolerant, regenerative, and used in all areas of cultivation of fodder (combined with Vegetation, hay, haylage, silage, and other crops, used as pasture). Therefore, it is necessary to study the agronomic techniques of Sudan grass and grow high-quality fodder [7]. Sudan grass is an annual brown grass, green yield is $60-80$ tons, and seed yield is 2.5 tons. $100 \mathrm{~kg}$ of Vegetation contain 22 fodder units and $2.8 \mathrm{~kg}$ of protein, while hay contains 57 fodder units and $7.4 \mathrm{~kg}$ of protein, respectively [8]. The nutritional value of Sudan grass is influenced by external environmental factors, soil and climatic conditions. Under the conditions of Karakalpakstan, $1 \mathrm{~kg}$ of Vegetation stores $664 \mathrm{~g}$ of water, $40.7 \mathrm{~g}$ of protein, $7.4 \mathrm{~g}$ of fat, $125 \mathrm{~g}$ of tissue, and 0.26 fodder units. These indicators are $739,52,11.1,78.2$, and 0.24 in the Khorezm province; in the Namangan province: $802.3 ; 23.1 ; 4.7 ; 73.7$; and 0.14 ; and, the average for Uzbekistan is equal to $724.7 ; 34.4 ; 6.6$; 97.1 ; and 0.22 fodder units, respectively [9].

Possibly, 4.97 tons/ha of hay and 0.72 tons/ha of protein were obtained when Sudan grass nay was harvested during the wrapping period; at the beginning of the ripening period, 4.79 tons/ha of hay and 0.56 tons/ha of protein, and at the time of full ripening, the hay yield was 4.72 tons/ha and the protein was 0.47 tons/ha. A decrease in the quality of Vegetation was observed during late harvest [10].

Sudan grass is sensitive to irrigation and collects well when irrigated. Accumulation nay averaged 7.5 during the wrapping period; during the growing season - 8.4; at flowering -9.1 and at re-growth - up to 10.0. Sudan grass is spread $15 \mathrm{~cm}$ between rows, sowing depth is 3-5 cm, and sowing rate is $0.5-2.0$ million seeds. 900 quintals (q)/ha of Vegetation were obtained when Sudan grass was planted at $25 \mathrm{~kg} / \mathrm{ha}$. Sudan grass harvesting cycles were studied and it was noted that the optimal harvesting time was nay wrapping ( 5 harvests, total yield $656.7 \mathrm{q} / \mathrm{ha}$ ) and the beginning phases of germination (3 harvests and total yield $753.1 \mathrm{q} / \mathrm{ha})[11]$.

In such experiments in Ontario (Canada), Sudan grass was grown in May-June with a row spacing of $18-36 \mathrm{~cm}$, a planting rate of $15 \mathrm{~kg} / \mathrm{ha}$, and a planting depth of $2-2.5 \mathrm{~cm} .65$ days after the first germination, the stems are harvested when they reach an average height of $65 \mathrm{~cm}$. The second harvest took place after 30-35 days [12].

A study by OS Korzun and otrhers analyzed that Sudan grass can also be grown on radiation-contaminated lands in various provinces of Belarus. Under such conditions, Sudan grass was found to contain $0.03+0.01$ and $4.9+1.6 \mathrm{mg}$ of cesium 137 and strontium 90 , respectively, which is lower than the permissible norms [13].

In the gray meadow soil conditions of the Syrdarya province, Sudan grass was studied by pure sowing $(16,20 \mathrm{~kg} / \mathrm{ha})$ and mixed with moss $(30 \mathrm{~kg} / \mathrm{ha})$ for repeated sowing on an area free of wheat. Due to the high air temperature in summer, the period of validity until harvest was 69 days at 50 percent flowering [14].

When Sudan grass $(20 \mathrm{~kg} / \mathrm{ha})$ and moss $(30 \mathrm{~kg} / \mathrm{ha})$ were added, the results were higher than other options on all biometric indicators of plants. At the end of the operation period, the actual seedling thickness was 739.100/ha in Sudan grass and 351,800 ha in mung bean, while the average height of Sudan grass was $265.0 \mathrm{~cm}$ and $53.95 \mathrm{~cm}$ in mung bean. Stems formed per hectare (1,182.6 in Sudan grass and 598.1 in mung bean) and a large number of leaves have been reported [15].

The planting rate of Sudan grass varieties in the soil conditions of dry steppe areas in 2000-2002 was studied at the Buryat Seed Experimental Station. The leaf area increased with the sowing rate: $25,2-30,500 \mathrm{~m}^{2}$ /ha by varieties when sowing 1.0 million seeds; 32,6 - 
$39,500 \mathrm{~m}^{2} /$ ha when sowing 1.5 million seeds; and, the seed rate was $36,0-43,600 \mathrm{~m}^{2} / \mathrm{ha}$ when the seed rate was 2.0 million [16].

In the black soil conditions of the foothills of the desert province of the Orenburg province (Russia), varieties of Sudan grass have been studied at different rates $(2.5 ; 3.0$; and, 3.5 million pieces/ha). Control 'Brodskaya-2' variety with a dry yield of 6.22 tons/ha in sandy soils when sowing 3 million seeds; average leaf area $20,200 \mathrm{~m}^{2} / \mathrm{ha}$; photosynthesis productivity was $5.73 \mathrm{~g} / \mathrm{m}^{2}[16]$.

At the Syrdarya Scientific Experimental Station in Uzbekistan, the norms of planting Sudan grass in pure form and mixed with moss were studied. Sudan grass in pure form at $16 \mathrm{~kg}$ per hectare was $30.2 \mathrm{~g}$ of leaf mass per plant; the leaf rate was $16.6 \%$, respectively, at $20 \mathrm{~kg}$ per hectare was $29.1 \mathrm{~g}$ and $16.5 \%$. In the mixed-planted variants of mung bean (30 $\mathrm{kg}$ ) and Sudan grass (16 and $20 \mathrm{~kg}$ ); all indicators were higher than those planted in pure form. Mung bean $30 \mathrm{~kg} / \mathrm{ha}+$ Sudan grass $16 \mathrm{~kg} / \mathrm{ha}$ When planted, a bush of Sudan grass has a leaf mass of $40.0 \mathrm{~g}$ and a moss of $6.1 \mathrm{~g}$, the proportion of leaves relative to the plant mass is $15.1 \%$ in Sudan grass, $44.5 \%$ in moss mung bean $30 \mathrm{~kg} / \mathrm{g}+$ Sudan grass $20 \mathrm{~kg} / \mathrm{ha}$ in the planted variant 35.5 and $5.0 \mathrm{~g}, 14.9 \%$ and $44.8 \%$, respectively [17].

In experiments in Kalmykia (Russia), varieties of Sudan grass have been studied by planting at different rates. Control 'Kamishinskaya' variety was planted 4.5 million pieces and received 10.6 tons/ha of hay. 'Bistryanka' variety sowed 5 million seeds and harvested 9.9 tons/ha of hay. 'Mnogootrastayushchaya' variety received 4.0-4.5 million seeds, 10.0410-63 tons/ha of hay. Photosynthesis capacity (PP) ranged from 2.20 to 3.93 million $\mathrm{m}^{2} / \mathrm{ha}$. The leaf area was $61,200 \mathrm{~m}^{2} /$ ha in the first harvest and $40,000 \mathrm{~m}^{2} /$ ha in the second harvest. The correlation between sowing rate and yield was high, ranging from $r=0.93-0.07$ [9].

\section{Materials and methods}

Scientific research to develop the most optimal recommendations for determining the norms, timing and harvesting dates of Sudan grass was conducted in 2017-2019 at the Syrdarya Scientific Experimental Station of the Research Institute of Cotton Breeding, Seed Production and Agrotechnology under moderately saline soil conditions.

Common technological guidelines were used in all technological activities, phenological observations and biometric measurements and calculations, as well as in the analysis of soil samples [6- 8, 17].

The experiment was conducted in a field style. The number of returns is 4 , the fields are in 4 tiers and the field surface is $15 \mathrm{~m}^{2}$. Sudan grass is planted in simple rows. The distance between the rows is $15 \mathrm{~cm}$. In each variant, $0.25 \mathrm{~m}^{2}$ plots were allocated from three places and observations were made.

Sudan grass was planted at the rates of 20,25 , and $30 \mathrm{~kg} / \mathrm{ha}$, and was harvested during the flowering, wrapping, and flowering periods. At the same time, the differences in the number of crops and the total yield during the period of operation, as well as the optimal options were identified. The nutrients and digestibility of the stems and leaves of Sudan grass vary with age, so by studying its harvesting period, the possibility of growing a nutritious blue mass and hay was determined.

During the experimental years, a variety 'Chimbayskaya yubileynaya' of Sudan grass was planted in the third decade of March.

\section{Results and discussion}

Sudan grass is a multi-crop plant and the number of stems increases from harvest to harvest. The re-growth of this crop after harvest and the increase in its number by forming 
additional stems depend on its biology. In the first round of Sudan grass experiments conducted in 2017-2019, the number of bushes increased from an average of 2.39 to 2.64 million, depending on the planting rate. In the second place, this figure ranged from an average of 6.18 to 8.28 million units. In the third place, this figure averaged 7.3.2-9.49 million units (Table 1).

It was harvested twice during the ripening phase. The number of bushes in the first crop of Sudan grass has increased from an average of 2.67 to 3.51 million in experimental years, depending on the planting rate. In the second round, the figure ranged from 5.11 to 7.35 million.

Table 1. Number of plants and density rate of Sudan grass (three-year average).

\begin{tabular}{|c|c|c|c|c|c|c|c|}
\hline \multirow{2}{*}{ Phases } & \multirow{3}{*}{ Harvests } & \multicolumn{4}{|c|}{$\begin{array}{c}\text { Number of plants, } \\
\text { million/ha }\end{array}$} & \multicolumn{4}{c|}{ Density, bush/pcs } \\
\cline { 3 - 8 } & & \multicolumn{6}{|c|}{ Planting norms, kg/ha } \\
\cline { 3 - 8 } & & $\mathbf{2 0}$ & $\mathbf{2 5}$ & $\mathbf{3 0}$ & $\mathbf{2 0}$ & $\mathbf{2 5}$ & $\mathbf{3 0}$ \\
\hline \multirow{3}{*}{ Germination (Ph1) } & $1(\mathrm{H} 1)$ & 2.39 & 2.64 & 2.60 & 2.5 & 2.1 & 1.7 \\
\cline { 2 - 8 } & $2(\mathrm{H} 2)$ & 6.18 & 7.49 & 8.28 & 6.4 & 6.1 & 5.4 \\
\cline { 2 - 8 } & $3(\mathrm{H} 3)$ & 7.30 & 8.49 & 9.49 & 7.6 & 7 & 6.2 \\
\hline \multirow{2}{*}{$\begin{array}{c}\text { Mid-phase, 50\% } \\
\text { (Ph2) }\end{array}$} & $1(\mathrm{H} 1)$ & 2.67 & 3.08 & 3.51 & 2.8 & 2.5 & 2.3 \\
\cline { 2 - 8 } & $2(\mathrm{H} 2)$ & 6.33 & 5.11 & 7.35 & 6.6 & 5.9 & 4.8 \\
\hline $\begin{array}{c}\text { Flowering, 50\% } \\
\text { (Ph3) }\end{array}$ & $1(\mathrm{H} 1)$ & 3.07 & 3.49 & 3.73 & 3.2 & 2.8 & 2.4 \\
\cline { 2 - 8 } & $2(\mathrm{H} 2)$ & 6.18 & 7.33 & 7.56 & 6.3 & 6.1 & 5.2 \\
\hline
\end{tabular}

It is also harvested twice during the flowering phase. In the first harvest of Sudan grass, the number of bushes increased from an average of 3.07 to 3.74 million, depending on the planting rate. In the second place, this figure ranged from 6.18 to 7.56 million units.

Experiments from the first year showed that the number of bushes increased when the sowing rate was increased from $20 \mathrm{~kg} / \mathrm{ha}$ to $30 \mathrm{~kg} / \mathrm{ha}$. An increase in the total number of stems was observed, forming additional stems from harvest to harvest. In the following years of the experiment, the same pattern was repeated.

In the experiment, it was noted that the increase in the sowing rate has an effect on the number and accumulation of bushes, a decrease in the level of accumulation. However, the rate of accumulation increased from harvest to harvest. When the sowing rate was $20 \mathrm{~kg} / \mathrm{ha}$, the accumulation rate per bush was 2.5 in the first harvest, 6.4 in the second harvest and 7.6 in the third harvest; 2.1 pieces at the sowing rate of $25 \mathrm{~kg} / \mathrm{ha} ; 6.0$ pieces in the second roll and 7.0 pieces in the third roll; 1.7 pieces in the first harvest when the sowing norm is 30 $\mathrm{kg}$; in the second harvest -5.4 and in the third harvest -6.2 stems.

Sudan grass accumulation rate has been observed to increase from the tube wrapping phase to the germination and flowering phases.

This means that when Sudan grass is harvested early, the number of crops increases and the rate of accumulation increases from crop to crop.

Mathematical correlation between the number of bushes and the degree of accumulation in Sudan grass sowing norms and harvest times when calculated by the method of BA Dospekhov, according to mathematical calculations, the results of the analysis of variance showed a positive correlation between these indicators. In particular, the correlation coefficient between the two indicators was $r=0.845\left(\mathrm{R}^{2}=0.36\right)$, indicating a high degree of positive correlation (Fig. 1). 


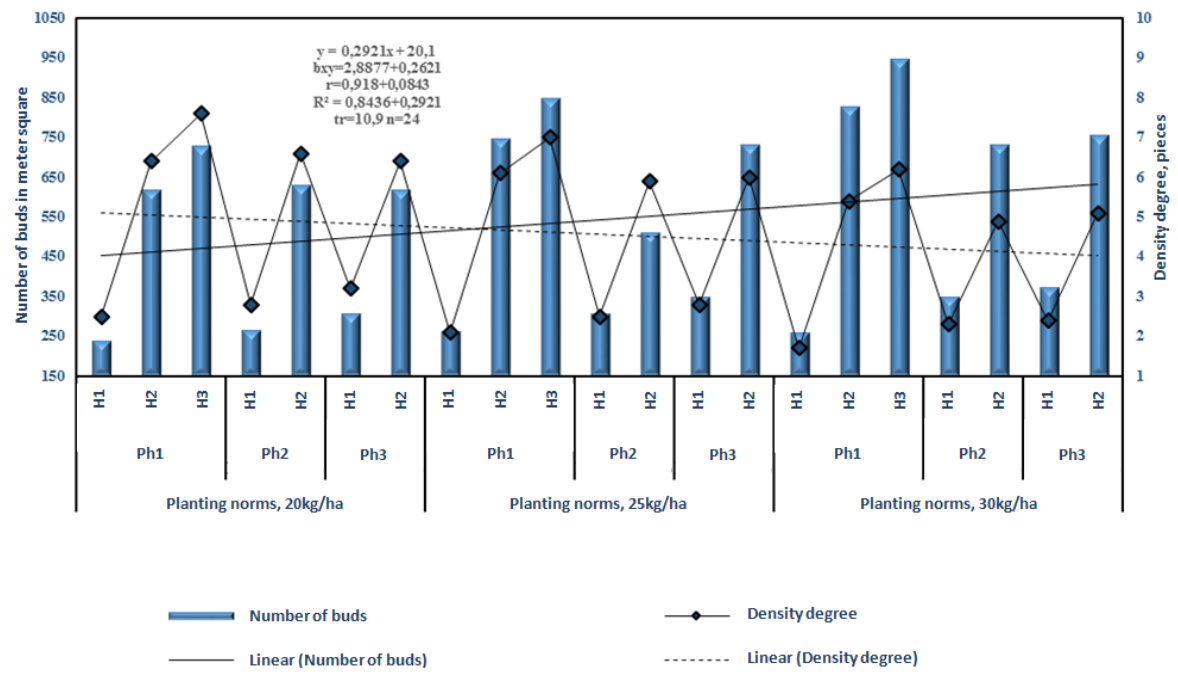

Fig. 1. Number and density of Sudan grass according to crop and planting norms (2017-2019).

The results of phenological observations showed that when Sudan grass was planted at a rate of $20 \mathrm{~kg} / \mathrm{ha}$, the developmental periods coincided with different dates for 2017-2019. The germination phase was first observed on June 30,15, and 20; the second harvest was observed on July 27, 14, 17; the third harvest was recorded on 23, 12, and 23 August. The ripening phase was first observed on July 15,3, and 10; the second harvest was recorded on August 26, 11, and 18. The flowering phase was first observed on July 20, 12, and 22; the second harvest was recorded on September 10, 5, and 15.

When Sudan grass was harvested in the germination phase of the application period, the first harvest lasted 47-41 days, the second harvest 28-30 days and the third harvest -27-30 days. When the Sudan grass was harvested during the growing season, the first harvest lasted 61-62 days and the second harvest 39-41 days. When Sudan grass is harvested during the flowering period, the first crop is harvested in 68-70 days, the second crop is harvested in 50-55 days.

When Sudan grass was harvested at different times, the number of crops was 2 or 3 . When Sudan grass is mowed 3 times, the supply of Vegetation to livestock during grazing is intensified. This should be taken into account when setting up a green conveyor.

It can also be seen from the data obtained that environmental factors and cultivation technology affect plant growth. Plant growth is one of the elements of crop formation.

Table 2. Influence of sowing rate and harvest time on Sudan grass growth, $\mathrm{cm}$ (three-year average).

\begin{tabular}{|c|c|c|c|c|}
\hline \multirow{2}{*}{ Phases } & \multirow{2}{*}{ Harvests } & \multicolumn{3}{|c|}{ Planting norms, kg/ha } \\
\cline { 3 - 5 } & & $\mathbf{2 0}$ & $\mathbf{2 5}$ & $\mathbf{3 0}$ \\
\hline \multirow{3}{*}{ Germination $(\mathrm{Ph} 1)$} & $1(\mathrm{H} 1)$ & 51.8 & 53.8 & 56.3 \\
\cline { 2 - 5 } & $2(\mathrm{H} 2)$ & 55.1 & 57.8 & 58.7 \\
\cline { 2 - 5 } & $3(\mathrm{H} 3)$ & 50.5 & 52.8 & 54.0 \\
\hline \multirow{2}{*}{ Mid-phase, 50\% (Ph2) } & $1(\mathrm{H} 1)$ & 128.3 & 134.8 & 138.8 \\
\cline { 2 - 5 } & $2(\mathrm{H} 2)$ & 136.0 & 139.0 & 142.6 \\
\hline \multirow{2}{*}{ Flowering, 50\%(Ph3) } & $1(\mathrm{H} 1)$ & 159.3 & 162.9 & 167.6 \\
\cline { 2 - 5 } & $2(\mathrm{H} 2)$ & 119.7 & 123.9 & 126.6 \\
\hline
\end{tabular}

An increase in stem height was observed as the sowing rate increased (Table 2). In Sudan grass experiments in 2017, the height of the stem in the first harvest was $55.5 \mathrm{~cm}$ when the sowing rate was $20 \mathrm{~kg} / \mathrm{ha}$ during the trimming period. Stem height was $5.4 \%$ 
higher when the planting rate exceeded $5 \mathrm{~kg} / \mathrm{ha}$; again, stems height was observed to be $9.2 \%$ higher when increased by $5 \mathrm{~kg} / \mathrm{ha}$.

In all planting norms in the second harvest, the stem grew better than in the first harvest. According to the planting norms, the height of the stem compared to the first harvest is 5.2 and 8.1 ; and increased by $1.8 \%$.

Two harvests were obtained when harvested during the ripening phase. The height of the stem was $143,145,151 \mathrm{~cm}$ in the first crop according to planting norms. In the second harvest, the stem height was 1.4, respectively, compared to the first harvest; 2.1 and $1.3 \%$ higher, respectively. During the flowering phase, Sudan grass is typical of biology. It was found that the height of the stem increased by $4.0 .7 .0 \mathrm{~cm}$ as the planting norms increased. The second crop did not reach the flowering period, so the stem height was $43-41 \mathrm{~cm}$ lower than the first crop.

This pattern was repeated in the 2018-2019 experiments. According to the average data from three years of experiments, when Sudan grass was harvested in the weeding phase and seeds were sown at $20 \mathrm{~kg} / \mathrm{ha}$, the stem height was $51.8-56.3 \mathrm{~cm}$ in the first harvest. Stem height increased by $2.0-4.5 \%$ due to the increase in planting rates. In the second harvest, the stem height was 6.3 compared to the first harvest due to favorable conditions for Sudan grass regrowth.

It is known that crop yields are formed by photosynthesis in leaves, so it is important to determine the effect of technological measures on leaf development and leaf surface formation in the plant. In the experiment, it was found that Sudan grass planting norms affected leaf development (Table 3).

Table 3. Dependence of Sudan grass number of leaves and surface formation on sowing rate and harvesting period (three-year average).

\begin{tabular}{|c|c|c|c|c|c|c|c|}
\hline \multirow{2}{*}{ Phases } & \multirow{2}{*}{ Harvests } & \multicolumn{3}{|c|}{ Number of leaves } & \multicolumn{3}{c|}{ Leaf surface, '000 $\mathbf{~ m}^{\mathbf{2}} / \mathbf{h a}$} \\
\cline { 3 - 8 } & & $\mathbf{2 0}$ & $\mathbf{2 5}$ & $\mathbf{3 0}$ & $\mathbf{2 0}$ & $\mathbf{2 5}$ & $\mathbf{3 0}$ \\
\hline \multirow{3}{*}{ Germination $(\mathrm{Ph} 1)$} & 1 & 4.6 & 4.2 & 3.5 & 31.6 & 36.2 & 35.5 \\
\cline { 2 - 8 } & 2 & 4.8 & 4.5 & 4.1 & 35.9 & 38.0 & 37.3 \\
\cline { 2 - 8 } & 3 & 4.5 & 4.1 & 3.6 & 33.1 & 36.3 & 34.9 \\
\hline \multirow{2}{*}{ Mid-phase, 50\% $(\mathrm{Ph} 2)$} & 1 & 6.4 & 5.7 & 5.2 & 41.3 & 43.6 & 42.8 \\
\cline { 2 - 8 } & 2 & 5.8 & 5.3 & 4.9 & 40.6 & 42.8 & 42.3 \\
\hline \multirow{2}{*}{ Flowering, 50\% $(\mathrm{Ph} 3)$} & 1 & 7.0 & 6.4 & 5.5 & 50.9 & 54.9 & 54.3 \\
\cline { 2 - 8 } & 2 & 6.1 & 5.6 & 4.9 & 47.9 & 53.2 & 52.1 \\
\hline
\end{tabular}

While the Sudan grass was harvested during the weeding period, the number of leaves decreased from 4.6 to 3.5 as the sowing rate in the first crop increased; in the second harvest it decreased from 4.8 to 4.1 and in the third harvest from 4.5 to 3.6. When the Sudan grass was harvested during the growing season, the number of leaves decreased from 6.4 to 5.2 as the sowing rate increased in the first harvest; in the second half, a decrease of 5.8 to 4.9 was observed. When Sudan grass is harvested during the flowering period, the number of leaves decreases from 7.0 to 5.5 as the sowing rate in the first crop increases; in the second half it decreased from 6.1 to 5.6.

Whereas the Sudan grass was harvested during the weeding period, the leaf area in the first crop was $31,600 \mathrm{~m}^{2} / \mathrm{ha}$ at the sowing rate of $20 \mathrm{~kg} / \mathrm{ha}$. It was found that the leaf area increased by $4,600 \mathrm{~m}^{2} /$ ha when the sowing rate was $25 \mathrm{~kg} / \mathrm{ha}$; it was noted that when the sowing rate increased to $30 \mathrm{~kg} / \mathrm{ha}$, the leaf surface decreased by $700 \mathrm{~m}^{2} / \mathrm{ha}$ from the previous variant. In the second half of the Sudan grass weeding period, the sowing rate was $35,900 \mathrm{~m}^{2} / \mathrm{ha}$ at $20 \mathrm{~kg} / \mathrm{ha}$. It was found that the leaf area increased by $2,100 \mathrm{~m}^{2} / \mathrm{ha}$ when the 
sowing rate was $25 \mathrm{~kg} / \mathrm{ha}$; when the planting rate increased to $30 \mathrm{~kg}$, the leaf surface decreased by $700 \mathrm{~m}^{2} /$ ha from the previous variant.

When the Sudan grass was harvested during the growing season, the leaf area in the first crop was $41,300 \mathrm{~m}^{2} / \mathrm{ha}$ at the sowing rate of $20 \mathrm{~kg} / \mathrm{ha}$. It was found that the leaf area increased by $2,300 \mathrm{~m}^{2} /$ ha when the sowing rate was $25 \mathrm{~kg} / \mathrm{ha}$; it was noted that when the planting rate increased to $30 \mathrm{~kg}$, the leaf surface decreased by $800 \mathrm{~m}^{2} /$ ha from the previous variant. In the second phase of the Sudan grass growth phase, the sowing rate was 40,600 $\mathrm{m}^{2} / \mathrm{ha}$ at $20 \mathrm{~kg} / \mathrm{ha}$. It was found that the leaf area increased by $2,200 \mathrm{~m}^{2} / \mathrm{ha}$ when the sowing rate was $25 \mathrm{~kg} / \mathrm{ha}$; it was noted that when the planting rate increased by $30 \mathrm{~kg} / \mathrm{ha}$, the leaf surface decreased by $700 \mathrm{~m}^{2} /$ ha from the previous variant.

Whilst the Sudan grass was harvested in the flowering phase, the leaf area was 50,900 $\mathrm{m}^{2} /$ ha in the first harvest when the sowing rate was $20 \mathrm{~kg} / \mathrm{ha}$. It was found that the leaf area increased by $4,000 \mathrm{~m}^{2} /$ ha when the sowing rate was $25 \mathrm{~kg} / \mathrm{ha}$; it was noted that when the planting rate increased to $30 \mathrm{~kg} / \mathrm{ha}$, the leaf surface decreased by $600 \mathrm{~m}^{2} / \mathrm{ha}$ from the previous variant. In the second phase of the Sudan grass flowering phase, the sowing rate was $47,900 \mathrm{~m}^{2} / \mathrm{ha}$ at $20 \mathrm{~kg} / \mathrm{ha}$. It was found that the leaf area increased by $5,300 \mathrm{~m}^{2} / \mathrm{ha}$ when the sowing rate was $25 \mathrm{~kg} / \mathrm{ha}$; it was noted that when the planting rate increased to 30 $\mathrm{kg} / \mathrm{ha}$, the leaf surface decreased by $11,000 \mathrm{~m}^{2} /$ ha from the previous variant.

The photosynthetic potential (PP) was 3.06 million $\mathrm{m}^{2}$ in a day/ha when $20 \mathrm{~kg}$ of seeds were sown per hectare when the three crops were harvested at the time of sowing; it was observed that the PP increased by 0.42 million $\mathrm{m}^{2}$ per day $/$ ha at the sowing rate of $25 \mathrm{~kg}$. When $30 \mathrm{~kg}$ of seeds were sown per hectare, it was found that this figure decreased by 0.34 million $\mathrm{m}^{2}$ per day/ha compared to the previous option. When Sudan grass $20 \mathrm{~kg}$ of seeds were planted and harvested in the germination phase, the PP was 3.42 million $\mathrm{m}^{2}$ in a day/ha. PP increased by 0.44 million $\mathrm{m}^{2} /$ day when sowing rate increased by $5 \mathrm{~kg} / \mathrm{ha}$; it was noted that the PP changed by 0.07 million $\mathrm{m}^{2} /$ day when the planting rate was increased by another $5 \mathrm{~kg} / \mathrm{ha}$. When Sudan grass $20 \mathrm{~kg}$ of seeds were planted and harvested during the flowering phase, the PP was 3.53 million $\mathrm{m}^{2}$ in a day/ha. PP increased by 0.14 million $\mathrm{m}^{2} /$ day when sowing rate increased by $5 \mathrm{~kg} / \mathrm{ha}$; it was noted that the PP changed by 0.11 million $\mathrm{m}^{2} /$ day when the planting rate was increased by another $5 \mathrm{~kg} / \mathrm{ha}$. It was found that the photosynthetic productivity of Sudan grass varies depending on the sowing rate and harvesting time. In the germination phase, photosynthesis productivity averaged 2.9 grams in the first crop with the lowest sowing rate, 3.1 grams when the sowing rate increased by 5 $\mathrm{kg} / \mathrm{ha}$, and 2.73 grams when the sowing rate increased by another $5 \mathrm{~kg} / \mathrm{ha}$.

In the germination phase, photosynthesis productivity in the lowest-sown variant averaged 3.42 grams in the first harvest, 3.86 grams when the sowing rate increased by 5 $\mathrm{kg} / \mathrm{ha}$, and 3.21 grams when the sowing rate increased by another $5 \mathrm{~kg} / \mathrm{ha}$.

In the flowering phase, the photosynthesis productivity in the lowest-sown variant averaged 3.53 grams in the first harvest, 3.67 grams when the sowing rate increased by 5 $\mathrm{kg} / \mathrm{ha}$, and 3.56 grams when the sowing rate increased by another $5 \mathrm{~kg} / \mathrm{ha}$.

Thus, the photosynthetic activity of Sudan grass varied depending on sowing norms and harvesting times, and high values were observed when sown at the rate of $25 \mathrm{~kg} / \mathrm{ha}$ in the second crop when harvested in the germination phase. High yields during the germination and flowering phases were observed when seeds were sown at the rate of $25 \mathrm{~kg} / \mathrm{ha}$ per hectare in the first harvest. When planted at $25 \mathrm{~kg} / \mathrm{ha}$, the photosynthetic potential in the flowering phase was 3.67 million $\mathrm{m}^{2} /$ ha, photosynthesis productivity was $4.65 \mathrm{~g} / \mathrm{m}^{2}$, leaf area was $54,9-53,200 \mathrm{~m}^{2} / \mathrm{ha}$.

Sudan grass is a fertile plant in terms of biology and is an influential plant in the technological activities carried out. In particular, it can be seen that the sowing rate and harvesting time during the application period affect the yield. 
The yield of Vegetation and hay from Sudan grass depends on the sowing rate and harvesting time, with 3 harvests obtained during the pruning phase and a high yield in the second harvest between harvests. At the sowing rate of $20 \mathrm{~kg} / \mathrm{ha}$, the first crop yielded $120.1 \mathrm{q} / \mathrm{ha}$. At the sowing rate of $25 \mathrm{~kg}$, the yield of Vegetation increased by $142.4 \mathrm{q} / \mathrm{ha}$; sowing norm again at $5 \mathrm{~kg} / \mathrm{ha}$, the yield increased by $1.2 \mathrm{q} / \mathrm{ha}$ compared to the previous option and harvested 2 times during pruning and flowering phases. It was observed that the yield was high in the second crop during the growing season. This pattern was observed in all experimental years (Table 4 and Fig. 2).

The yield of Vegetation in the second crop of Sudan grass was 17.1, respectively, compared to the first crop in terms of planting norms; 9.8 ; and an increase of $15.6 \%$. When harvested in the germination phase, the total yield was $373.9 \mathrm{q} / \mathrm{ha}$ to $442.2 \mathrm{q} / \mathrm{ha}$. In the first harvest of the germination phase, the yield of Vegetation was $285.3 \mathrm{q}$ when $20 \mathrm{~kg}$ of seeds were sown per hectare. When the sowing rate increased by $5 \mathrm{~kg} / \mathrm{ha}$, the yield of Vegetation was $330.4 \mathrm{q} / \mathrm{ha}$, and when the sowing rate was increased by $5 \mathrm{~kg} / \mathrm{ha}$, the yield of Vegetation was $332.2 \mathrm{q} / \mathrm{ha}$. In the second harvest, high green yields were obtained, compared to the first harvest by 5.6; 3.6; Yield increased by $2.1 \%$. The total yield of seedlings was 65.6 and $2.7 \mathrm{q} / \mathrm{ha}$, respectively, according to the sowing norms in relation to the yield obtained in the germination phase. When Sudan grass was harvested in the flowering phase, $453.7 \mathrm{q} / \mathrm{ha}$ of Vegetation was obtained when the first crop was planted in small quantities; $499.3 \mathrm{q}$ were obtained when the sowing rate was $25 \mathrm{~kg} / \mathrm{ha}$; when the sowing rate increased by another 5 $\mathrm{kg} / \mathrm{ha}$, the yield of Vegetation decreased by $34.0 \mathrm{q} / \mathrm{ha}$. When the first crop of Sudan grass was harvested in the flowering phase, the second crop also did not complete the flowering period, so it was observed that its green yield was high. In the second harvest, the yield was $265.7 \mathrm{q}$ to $287.7 \mathrm{q}$. When harvested in the flowering phase, Sudan grass yielded high green yields at all planting rates: from $719.4 \mathrm{q} /$ ha to $785.0 \mathrm{q} / \mathrm{ha}$, while at the sowing rate of 30 $\mathrm{kg} /$ ha the yield decreased by $32 \mathrm{q} / \mathrm{ha}$ (see Table 5).

Table 4. Photosynthetic potential and photosynthetic productivity of Sudan grass (three-year average).

\begin{tabular}{|c|c|c|c|c|c|c|c|}
\hline \multirow{3}{*}{ Phases } & \multirow{3}{*}{ Harvests } & \multicolumn{3}{|c|}{$\begin{array}{l}\text { Photosynthetic potential, } \\
\text { million } \mathrm{m}^{2} \text { in a day/ha }\end{array}$} & \multicolumn{3}{|c|}{$\begin{array}{l}\text { Photosynthesis productivity, } \\
\qquad \mathrm{g} / \mathrm{m}^{2}\end{array}$} \\
\hline & & \multicolumn{6}{|c|}{ Planting norms, kg/ha } \\
\hline & & 20 & 25 & 30 & 20 & 25 & 30 \\
\hline \multirow{3}{*}{$\mathrm{Ph} 1$} & 1 & 0,96 & 1,14 & 0,98 & 2,8 & 3,0 & 2,7 \\
\hline & 2 & 1,12 & 1,27 & 1,15 & 3,0 & 3,2 & 2,8 \\
\hline & 3 & 0,98 & 1,07 & 1,00 & 2,9 & 3,1 & 2,7 \\
\hline Total & & 3,06 & 3,48 & 3,14 & 2,9 & 3,1 & 2,73 \\
\hline \multirow{2}{*}{$\mathrm{Ph} 2$} & 1 & 1,75 & 1,95 & 1,67 & $3,5^{*}$ & 4,0 & 3,8 \\
\hline & 2 & 1,67 & 1,86 & 1,54 & 3,4 & 3,9 & 3,7 \\
\hline Total & & 3,42 & 3,86 & 3,21 & 3,45 & 3,95 & 3,75 \\
\hline \multirow{2}{*}{$\mathrm{Ph} 3$} & 1 & 1,78 & 1,81 & 179 & 4,3 & 4,8 & 4,5 \\
\hline & 2 & 1,75 & 1,76 & 1,77 & 4,2 & 4,5 & 4,0 \\
\hline Total & & 3,53 & 3,67 & 3,56 & 4,25 & 4,65 & 4,25 \\
\hline
\end{tabular}

* The average product of photosynthesis has been determined for this value 


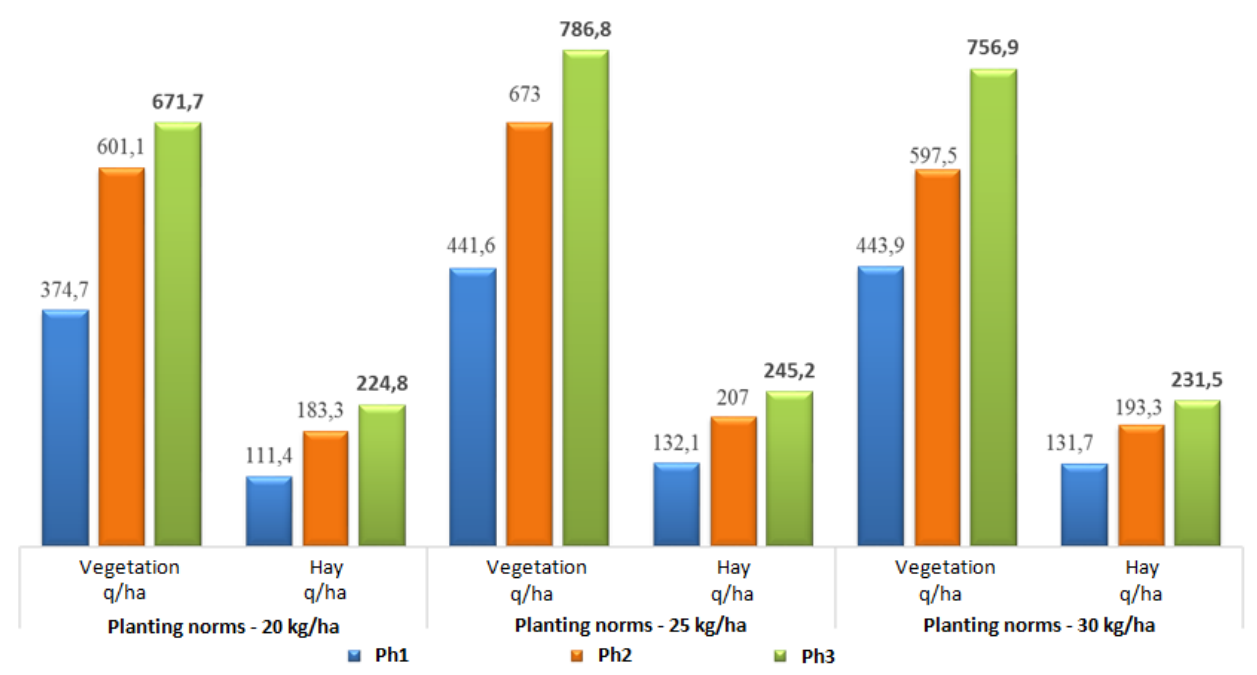

Fig. 2. Grass and hay yield of Sudan grass (three-year average).

A similar pattern was observed in other years of experience. High green yields over the years were obtained in the second year of experiments - in 2018 when sowing seeds of 25$30 \mathrm{~kg} / \mathrm{ha}$.

According to the three-year average data, Sudan grass was sown with $20 \mathrm{~kg}$ of seeds per hectare and harvested in the first stage, yielding $119.2 \mathrm{q} /$ ha of Vegetation in the first harvest.

It was found that when the sowing rate was $25 \mathrm{~kg} / \mathrm{ha}$, the yield was $143 \mathrm{q} / \mathrm{ha}$, and when the sowing rate was increased by $5 \mathrm{~kg} / \mathrm{ha}$, the yield of Vegetation was $133.7 \mathrm{q} / \mathrm{ha}$, which is $9.3 \mathrm{q} / \mathrm{ha}$ less than in the previous variant. The yield of Vegetation in the second crop of Sudan grass was 18.1, respectively, compared to the first crop in terms of planting norms; 16.0 ; and an increase of $12.1 \%$. When harvested in the germination phase, the total yield was $374.7 \mathrm{q} / \mathrm{h}$ a to 441.6 and $431.2 \mathrm{q} / \mathrm{ha}$. When harvested in the germination phase, the yield of Vegetation in the first harvest was $290.5 \mathrm{q} / \mathrm{ha}$ when $20 \mathrm{~kg}$ of seeds were sown per hectare. When the sowing rate exceeded $5 \mathrm{~kg} / \mathrm{ha}$, the yield of Vegetation was $39.4 \mathrm{q} / \mathrm{ha}$ higher; when the sowing rate was increased by another $5 \mathrm{~kg} / \mathrm{ha}$, the yield of Vegetation decreased by $38.5 \mathrm{q} / \mathrm{ha}$ compared to the previous option. In the second harvest, high green yields were obtained, compared to the first harvest by $5.6 ; 3.6$; and increased yields by $5.3 \%$. When the total planting yield increased by $25-30 \mathrm{~kg}$ during the germination phase, an additional $66.2-69 \mathrm{q} / \mathrm{ha}$ of seedlings were obtained compared to the $20 \mathrm{~kg}$ norm.

Hay yields averaged $35.7 \mathrm{q} / \mathrm{ha}$ in the first harvest when $20 \mathrm{~kg}$ of seeds were sown per hectare of Sudan grass per hectare, according to the average three-year data. When the sowing rate was $25 \mathrm{~kg} / \mathrm{ha}$, the yield was $42.7 \mathrm{q} / \mathrm{ha}$; and, when the sowing rate was increased to $5 \mathrm{~kg} / \mathrm{ha}$, the hay yield was $41.8 \mathrm{q} / \mathrm{ha}$. The yield of hay in the second crop of Sudan grass was 6.9, respectively, compared to the first crop in terms of sowing norms; 4.9; and an increase of $6.7 \%$. When harvested in the germination phase, the total crop yield was 111.4 $\mathrm{q} / \mathrm{ha}$ to $132.1 \mathrm{q} /$ ha of hay. When harvested in the germination phase, the hay yield in the first harvest was $88.6 \mathrm{q} / \mathrm{ha}$ when $20 \mathrm{~kg}$ of seeds were sown per hectare. Hay yield was 12.4 $\mathrm{q} /$ ha higher when the sowing rate exceeded $5 \mathrm{~kg} / \mathrm{ha}$; when the sowing rate was increased by another $5 \mathrm{~kg} / \mathrm{ha}$, the hay yield decreased by $12.2 \mathrm{q} / \mathrm{ha}$ compared to the previous variant. The second harvest yielded high hay, 6.9 according to the sowing norms compared to the first harvest; 4.9 ; and a yield increase of $6.5 \%$. 
Table 5. Vegetation and hay harvest of Sudan grass.

\begin{tabular}{|c|c|c|c|c|c|c|c|}
\hline \multirow{3}{*}{ Phases } & \multirow{3}{*}{ Harvests } & \multicolumn{3}{|c|}{ Vegetation yield, $\mathrm{q} / \mathrm{ha}$} & \multicolumn{3}{|c|}{ Hay yield, $\mathrm{q} / \mathrm{ha}$} \\
\hline & & \multicolumn{6}{|c|}{ Planting norms, $\mathrm{kg} / \mathrm{ha}$} \\
\hline & & 20 & 25 & 30 & 20 & 25 & 30 \\
\hline \multicolumn{8}{|c|}{2017} \\
\hline \multirow{4}{*}{ Ph1 } & 1 & 120.1 & 142.5 & 143.7 & 37.5 & 44.5 & 45.2 \\
\hline & 2 & 140.7 & 166.3 & 167.7 & 44 & 52 & 52.3 \\
\hline & 3 & 113.1 & 130.7 & 130.8 & 35.3 & 40.8 & 40.9 \\
\hline & Total & 373.9 & 439.5 & 442.2 & 116.8 & 137.3 & 138.49 \\
\hline \multirow{3}{*}{$\mathrm{Ph} 2$} & 1 & 285.3 & 330.4 & 332.2 & 89.2 & 103.3 & 103.6 \\
\hline & 2 & 305.1 & 342.3 & 341.4 & 95.3 & 107 & 108.8 \\
\hline & Total & 590.4 & 672.7 & 695.6 & 184.5 & 210.3 & 212.4 \\
\hline \multirow{3}{*}{$\mathrm{Ph} 3$} & 1 & 453.7 & 499.3 & 465.3 & 141.8 & 156 & 157.5 \\
\hline & 2 & 265.7 & 285.7 & 287.7 & 83 & 89.3 & 90.6 \\
\hline & Total & 719.4 & 785 & 753.0 & 224.8 & 245.3 & 248.1 \\
\hline $\begin{array}{c}\text { LSD }_{05} \\
\text { q/ha }\end{array}$ & & 9.69 & 19.94 & 14.78 & 1.94 & 6.85 & 9.33 \\
\hline $\mathrm{LSD}_{05}, \%$ & & 1.77 & 3.28 & 2.39 & 1.19 & 3.59 & 4.69 \\
\hline \multicolumn{8}{|c|}{2018} \\
\hline \multirow{4}{*}{$\mathrm{Ph} 1$} & 1 & 130 & 147.8 & 149.6 & 35.4 & 40.3 & 41.0 \\
\hline & 2 & 171 & 185.3 & 185.9 & 47.0 & 52.3 & 52.6 \\
\hline & 3 & 141.8 & 157.7 & 158.4 & 39.0 & 43.2 & 43.8 \\
\hline & Total & 442.8 & 490.8 & 493.4 & 108.3 & 135.8 & 137.4 \\
\hline \multirow{3}{*}{$\mathrm{Ph} 2$} & 1 & 328 & 364 & 365 & 95.8 & 107.4 & 107.7 \\
\hline & 2 & 354.3 & 378 & 379 & 103.8 & 114.5 & 115.5 \\
\hline & Total & 682.3 & 742 & 744 & 199.6 & 221.9 & 223.2 \\
\hline \multirow{3}{*}{$\mathrm{Ph} 3$} & 1 & 505 & 525 & 506 & 159.1 & 165.4 & 166.0 \\
\hline & 2 & 250 & 262 & 264 & 75 & 78.6 & 79.0 \\
\hline & Total & 755 & 787 & 770 & 234.1 & 244 & 245.4 \\
\hline $\begin{array}{c}\mathrm{LSD}_{05} \\
\text { q/ha }\end{array}$ & & 3.09 & 11.35 & 9.51 & 3.97 & 9.59 & 11.40 \\
\hline $\mathrm{LSD}_{05}, \%$ & & 3.59 & 1.70 & 1.38 & 2.29 & 4.80 & 4.49 \\
\hline \multicolumn{8}{|c|}{2019} \\
\hline \multirow{4}{*}{$\mathrm{Ph} 1$} & 1 & 109.3 & 138.6 & 125.9 & 34.2 & 43.3 & 39.3 \\
\hline & 2 & 113.0 & 146.0 & 132.3 & 35.3 & 45.6 & 41.3 \\
\hline & 3 & 85.1 & 110 & 99.5 & 26.6 & 34.4 & 31.1 \\
\hline & Total & 307.4 & 394.6 & 357.7 & 96.1 & 123.3 & 111.8 \\
\hline \multirow{3}{*}{$\mathrm{Ph} 2$} & 1 & 258.2 & 295.4 & 176.9 & 80.7 & 92.3 & 55.3 \\
\hline & 2 & 272.4 & 309.1 & 189.1 & 85.1 & 96.6 & 59.1 \\
\hline & Total & 530.6 & 604.5 & 366 & 165.8 & 188.9 & 114.4 \\
\hline \multirow{3}{*}{$\mathrm{Ph} 3$} & 1 & 419.3 & 483.3 & 456.1 & 131.0 & 151.0 & 142.5 \\
\hline & 2 & 270.4 & 305.1 & 300.7 & 84.5 & 95.3 & 106.6 \\
\hline & Total & 689.7 & 788.4 & 756.6 & 215.5 & 246.4 & 249.1 \\
\hline $\begin{array}{c}\mathrm{LSD}_{05} \\
\mathrm{q} / \mathrm{ha}\end{array}$ & & 9.97 & 8.62 & 4.99 & 5.60 & 5.13 & 9.42 \\
\hline $\operatorname{LSD}_{05}, \%$ & & 2.89 & 1.49 & 1.98 & 3.39 & 2.88 & 4.97 \\
\hline
\end{tabular}

A yield of $144.0 \mathrm{q} /$ ha of hay was obtained when the Sudan grass was harvested in the flowering phase and planted in small quantities in the first harvest; $157.5 \mathrm{q}$ were obtained when the sowing rate was $25 \mathrm{~kg} / \mathrm{ha}$; when the sowing rate increased by another $5 \mathrm{~kg} / \mathrm{ha}$, the hay yield was 155.3 q. When the first crop of Sudan grass was harvested in the flowering phase, the second crop did not reach the flowering period, so it was observed that its hay yield was low. During the flowering phase, Sudan grass was yielded 224.8-245.2-231.5 
$\mathrm{q} /$ ha of high hay at all planting norms. Hence, high yields were obtained under experimental conditions when Sudan grass was harvested to obtain Vegetation and hay when $50 \%$ entered the flowering phase. At all harvest times, high rates were observed when $25 \mathrm{~kg}$ of seeds were sown per hectare (see Fig. 2).

In addition to the yield of Vegetation and hay obtained during the cultivation of fodder crops, the amount of feed unit and protein is assessed, as the consumption of fodder and the amount of livestock product grown depends on its quality. It is known that an average of 100 grams of protein per unit of feed. If the amount of protein is different from this requirement, the quality of the pet product obtained will be different.

In Sudan grass harvesting during the weeding period, in the 2017 experiments, the feed unit was $20.4 \mathrm{q} / \mathrm{ha}$ when the sowing rate in the first crop was $20 \mathrm{~kg} / \mathrm{ha}$. It was found that the feed unit increased to $24.1 \mathrm{q} / \mathrm{ha}$ when the sowing rate was $25 \mathrm{~kg} / \mathrm{ha}$; it was noted that the feed unit decreased by $1.0 \mathrm{q} / \mathrm{ha}$ from the previous variant when the sowing rate increased to $30 \mathrm{~kg} / \mathrm{ha}$. In the second half of the Sudan grass weeding period, the sowing rate was 23.9 $\mathrm{q} / \mathrm{ha}$ at $20 \mathrm{~kg} / \mathrm{ha}$. It was found that the feed unit increased to $28.3 \mathrm{q} / \mathrm{ha}$ when the sowing rate was $25 \mathrm{~kg} / \mathrm{ha}$; it was noted that when the sowing rate increased to $30 \mathrm{~kg}$, the feed unit increased by $0.7 \mathrm{q} /$ ha from the previous variant.

When Sudan grass was harvested during the growing season, the feed unit was 48.5 $\mathrm{q} / \mathrm{ha}$ when the sowing rate in the first crop was $20 \mathrm{~kg} / \mathrm{ha}$. In the second crop of the Sudan grass germination phase, the sowing rate was $48.5 \mathrm{q} / \mathrm{ha}$ at $20 \mathrm{~kg} / \mathrm{ha}$. It was found that the feed unit increased by $4.3 \mathrm{q} / \mathrm{ha}$ when the sowing rate was $25 \mathrm{~kg} / \mathrm{ha}$; it was noted that when the sowing rate increased by $30 \mathrm{~kg} / \mathrm{ha}$, the feed unit increased by $3.5 \mathrm{q} / \mathrm{ha}$ from the previous option.

When Sudan grass was harvested in the flowering phase, the feed unit was $77.1 \mathrm{q} / \mathrm{ha}$ when the sowing rate in the first crop was $20 \mathrm{~kg} / \mathrm{ha}$. It was found that the feed unit increased by $7.8 \mathrm{q} / \mathrm{ha}$ when the sowing rate was $25 \mathrm{~kg} / \mathrm{ha}$; it was noted that the feed unit increased by $1.9 \mathrm{q} / \mathrm{ha}$ from the previous variant when the sowing rate increased to $30 \mathrm{~kg}$. In the second half of the Sudan grass flowering phase, the sowing rate was $45.2 \mathrm{q} / \mathrm{ha}$ at 20 $\mathrm{kg} / \mathrm{ha}$. It was found that the feed unit increased by $3.3 \mathrm{q} / \mathrm{ha}$ when the sowing rate was 25 $\mathrm{kg} / \mathrm{ha}$; it was noted that the feed unit increased by $2.9 \mathrm{q} / \mathrm{ha}$ from the previous variant when the sowing rate increased to $30 \mathrm{~kg} / \mathrm{ha}$. In general, the nutrient unit was found to increase with the sowing rate of Sudan grass during the growing season and with late mowing.

Table 6. Influence of planting time and harvest phase on Sudan grass nutrient content (three-year average).

\begin{tabular}{|c|c|c|c|c|c|c|c|}
\hline \multirow{3}{*}{ Phases } & \multirow{3}{*}{ Harvests } & \multicolumn{5}{|c|}{ Food unit, q/ha } & \multicolumn{3}{c|}{ Proteins, kg/ha } \\
\cline { 3 - 8 } & & $\mathbf{2 0}$ & $\mathbf{2 5}$ & $\mathbf{3 0}$ & $\mathbf{2 0}$ & $\mathbf{2 5}$ & $\mathbf{3 0}$ \\
\cline { 2 - 8 } & 1 & 19.0 & 23.1 & 22.8 & 154.5 & 184.4 & 185.4 \\
\hline \multirow{3}{*}{ Ph1 } & 2 & 22.6 & 26.8 & 26.5 & 182.6 & 214.0 & 213.8 \\
\cline { 2 - 8 } & 3 & 18.2 & 21.3 & 21.3 & 146.2 & 171.3 & 172.7 \\
\cline { 2 - 8 } & Total & $\mathbf{5 9 . 8}$ & $\mathbf{7 1 . 2}$ & $\mathbf{7 0 . 6}$ & $\mathbf{4 8 3 . 3}$ & $\mathbf{5 6 9 . 7}$ & $\mathbf{5 7 1 . 9}$ \\
\hline \multirow{3}{*}{$\mathrm{Ph} 2$} & 1 & 42.5 & 49.9 & 51.7 & 374.7 & 425.4 & 390 \\
\cline { 2 - 8 } & 2 & 46.6 & 52.1 & 54.9 & 400.7 & 442.6 & 410.8 \\
\cline { 2 - 8 } & Total & $\mathbf{8 9 . 1}$ & $\mathbf{1 0 2 . 0}$ & $\mathbf{1 0 6 . 6}$ & $\mathbf{7 7 5 . 4}$ & $\mathbf{8 6 8 . 0}$ & $\mathbf{8 0 0 . 9}$ \\
\hline \multirow{3}{*}{$\mathrm{Ph} 3$} & 1 & 68.3 & 76.1 & 75.5 & 559.2 & 648.2 & 648.2 \\
\cline { 2 - 8 } & 2 & 38.8 & 42.7 & 51.6 & 338.0 & 366.8 & 392.2 \\
\cline { 2 - 8 } & Total & $\mathbf{1 0 7 . 1}$ & $\mathbf{1 1 8 . 8}$ & $\mathbf{1 2 7 . 1}$ & $\mathbf{8 9 7 . 2}$ & $\mathbf{1 0 1 5 . 0}$ & $\mathbf{1 0 4 0 . 4}$ \\
\hline
\end{tabular}


Due to the fact that Sudan grass belongs to the family of legumes, the nutrient unit is less than that of legumes. However, there is an impact of technological measures on nutrient unit and protein content.

In the experiment, the amount of protein under the influence of the sowing norm when mowing Sudan grass in the weeding phase ranged from $483.3 \mathrm{~kg}$ to $571.9 \mathrm{~kg}$; protein content from $559.2 \mathrm{~kg}$ to $648.2 \mathrm{~kg}$ when harvested in the ripening phase; in the flowering phase - 897.2-1040.4 kg/ha. From this, it can be seen that the nutritional value of Sudan grass depends on the sowing rate and harvesting time. The protein supply of one feed unit is $79.8 \mathrm{~g}$ in the germination phase; during fermentation - $88.2 \mathrm{~g}$; during flowering - 87.1 grams (see Table 6).

\section{Conclusions}

Early mowing of Sudan grass increases the number of crops and the rate of accumulation increases from harvest to harvest, creating an opportunity to provide livestock with greenery during grazing and can be a green conveyor element.

In Sudan grass, stem growth was affected by planting norms and harvesting phases, and it was observed that stems were higher when sowing norms were increased and late (in the flowering phase) mowing. In the second harvest, the stem height was 6.3 compared to the first harvest due to favorable conditions for Sudan grass regrowth; 7.4 and 4.3\% higher.

The photosynthetic activity of Sudan grass varied depending on planting norms and harvesting phases, and high values were detected during germination and flowering phases. When planted at $25 \mathrm{~kg}$ per hectare, the photosynthetic potential in the flowering phase was 3.67 million $\mathrm{m}^{2} /$ ha, photosynthesis productivity was $4.65 \mathrm{~g} / \mathrm{m}^{2}$, leaf area was $54,9-53,200$ $\mathrm{m}^{2} /$ ha.

In all harvesting phases, high Vegetation and hay yields were observed when $25 \mathrm{~kg}$ of seeds were sown per hectare. The highest yield during the application period was obtained when Sudan grass was harvested during the flowering phase. Hence, high yields were obtained under experimental conditions when Sudan grass was harvested to obtain Vegetation and hay when $50 \%$ entered the flowering phase. At all harvest periods, high rates were observed when $25 \mathrm{~kg}$ of seeds were sown per hectare.

The nutrient content of Sudan grass depends on technological measures, and it has been found that high rates increase when the planting rate is increased and when harvested during the flowering phase.

\section{References}

1. S. Islamov, N. Namozov, M. Saidova, D. Kodirova, E3S Web of Conferences, 244, 03028 (2021)

2. Kh.N. Atabaeva, J.B. Khudoykulov, Plant Sciences, 255-256 (2018)

3. N.Ch. Namozov, D.A. Kodirova, M.I. Usmonova, International journal of scientific \& technology research, 9(03), 5491-5493 (2020)

4. M. Urmanova, A. Kuziev, D. Burkhanova, D. Kadirova, N. Namozov, N. Shadieva, E3S Web of Conferences, 244, 02036 (2021)

5. N. Namozov, M. Tursinbaev, I. Yuldoshev, S. Yuldasheva, E3S Web of Conferences, 244, 02007 (2021)

6. M. Karimov, N. Namozov, B. Teshaboev, E3S Web of Conferences, 244, 02025 (2021)

7. R.A. Kulmatov, A.A. Kist, IND. LAB, 44(12), 1689-1692 (1978) 
8. V.M. Emets, R.A. Kulmatov, Doklady Biological Sciences, 271(1-6), 370-372 (1983)

9. B. Abdullaev, R.A. Kulmatov, A.A. Kist, Industrial Laboratory (USSR) (English translation of Zavodskaya Laboratoriya), 54(7), 710-713 (1989)

10. V.S. Savenko, R.A. Kulmatov, Geochemistry International, 35(11), 1028-1030 (1997)

11. R.A. Kulmatov, V.S. Savenko, N. Dalonov, Geochemistry International, 29(5), 140148 (1992)

12. G.K. Mirsharipova, D.M. Mustafokulov, L.K. Karshiboeva, Z.N. Madrahimova, Journal of Agricultural Science of Uzbekistan, 3(81), 97-102 (2020)

13. G.K. Mirsharipova, D.M. Mustafokulov, Current issues in the cultivation of agricultural crops and prospects for its development, 579-584 (2020)

14. A. Kushkhov, N. Berbekova, A. Zhurtova, E3S Web of Conferences, 262, 01012 (2021)

15. E. Vertikova, V. Pylnev, E3S Web of Conferences, 247, 01057 (2021)

16. G.K. Mirsharipova, D.M. Mustafaqulov, L.A. Botirova, B.I. Kushbakov, B.S. Kasimov, Journal of Critical Reviews, 7(17), 2322-2333 (2020)

17. Sh.M. Turdimetov, G.K. Mirsharipova, D.M. Mustafakulov, L.A. Botirova, A.X. Abdujalilova, Journal Of Critical Reviews, 7(17), 2220-2234 (2020) 